\title{
Creativity in EFL Learners' Writing Through the Use of Poetry and Visualization
}

\author{
Hajar Ahmadi ${ }^{1}$, Fatemeh Mozaffari ${ }^{2}$, Abutaleb Iranmehr ${ }^{3}$

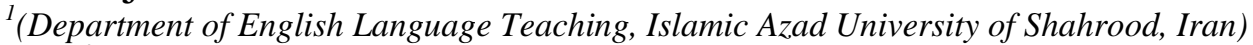 \\ ${ }^{2}$ (Department of English Language, Shahrood University of Technology, Iran) \\ 3(Department of English Language, Shahrood University of Technology, Iran)
}

\begin{abstract}
Writing task is less practiced and is not taken seriously into account in Iranian EFL classrooms. Learners' writing often lacks creativity and does not encourage or grasp the attention of readers. Since producing a creative writing requires education and practice, the current study is to explore the effect of poetry writing and visualization on writing creativity of EFL learners. To aim this, fifty EFL intermediate level learners were selected by random cluster sampling, among eight classes of the same level and were randomly assigned into control and experimental groups. TOEIC writing test was used containing parallel forms of writing tests and was scored by two independent raters. The teacher, in experimental group, read the selected poems providing explanations regarding its literary devices to clarify the scenes and then the students were asked to visualize the events and rewrite the poem. Control group followed the routine writing tasks of the institute. After ten sessions of the treatment, both groups went through a posttest. Mean score of two groups were compared. The results of the study showed changes and improvements in students' pieces of writing.
\end{abstract}

Keywords -Writing Creativity, Visualization, Poetry, EFL Learners

\section{INTRODUCTION}

Unlike speaking, writing a text, a paragraph, or even a sentence challenges the writer to think and write in the best way possible. As a result, the idea of writing creatively comes to the minds of writers and they try to write effectively. People wrongly suppose that writing effectively needs intelligence. In the refutation of this supposition Kane claims that writing English clearly and effectively does not require writers to be genius. Instead, writing effectively is a learnable skill and you can learn how to write by learning how to handle words, sentences, and paragraphs. [1]Barbot, Tan, Randi, Santa-Donato, and Grigorenko by interpreting experts' ideas reached to several ingredients that foster writing creativity.[2] They mentioned observation, intrinsic motivation, imagination, and description as ingredients that improve writing creativity. Among these ingredients the most important one was imagination factor.

Yavuz suggested the effective approaches and models of using literature in EFL classroom which would lead to enhance the students' creativity. The author got the point through presenting and reviewing some experts' work. The main purpose of this study was recommending teachers how to integrate the experience of poetry writing to their teaching program. At first, the advantage of using poetry was defined as making the students to transform their feelings into communicative force. Then Yavuz defined poetry as productive use of linguistic structure, aiding language acquisition, and allowing the use of different linguistic devices in an authentic context. [3] At last the teachers were suggested to engage the students in poetry writing through taskbased learning activities in communicative language classes to maximize the students' understanding of poetry. Smith found that poems, stories, and songs as the most powerful instruments to motivate the learners to write carefully. [4] Similar to Smith, Llach conducted a study by applying the poem Waste Land in the classroom and found that the poem had motivated students strongly. [5]

Reinforcement of students' knowledge of vocabulary, grammar alongside creative writing improvement was investigated by Kirkgoz.Findings revealed the educational and entertainment value of poems. [6] Students' knowledge, motivation, enjoyment, and relaxation along with their self-confidence and imagination were enriched. Since importance of imagination was discovered as an influencing factor on writing creativity, the researcher decided to consider poetry writing and visualization (imagination) to improve writing creativity in subjects of the study.

Finally, Ward described methods by which the integration of poetry and writing may engage and motivate English students. At the end, she suggested six strategies to be applied in the EFL classroom to engage the learners. At first, she concluded that poetry writing increases the learner's emotional growth and critical thinking, and enabling them to understand both the meaning of the poem and the reason of writing it. Then she suggested strategies such as Sketch to stretch, Quick writes, Venn diagrams, Text graphic representations, 
Poetry writing, and Narrative writing.[7]Jeffery discovered the common features and characteristics of creative teaching, creative learning and the meaningful nature of these experiences. [8] The findings of this study were in line of some other experts' arguments in which relevance; control, ownership, and innovation elements were expressed as the characteristics of the creative teaching. Furthermore, Glenn was interested in finding the way that writing fiction not related to what has been read affects reading skills and behaviors of the students. He found the participants so motivated to improve their story writings that lead them to make use of other authors' texts to explore the applied techniques in conveying the stories.[9] Therefore, they went through different texts with the purpose of extracting writing skills out of them.

In the same way Chen and Zhou described the kind of creative writing strategies used by Chinese children in communication and the way those strategies conveyed children's thoughts. They also investigated the effect of the educational environment on the children's creative writing strategies. The strategies employed by the children were making use of "(1) pictures of objects or (2) pictures of objects which have the same pronunciation of the target characters, and (3) alternative characters which have the same pronunciations with those of target characters." [10] The findings of this study indicated the tight relationship between the children's writing development and drawings. The pictures were used by the Chinese children for two purposes: a usual way to convey meaning and a part of writing system.

The integration of image-making activity with the writing process and making writing a work of art was the concern of Olshansky, accomplished through an empirical study. Throughout this approach the learners with different learning styles were attracted in this process. [11] In this experiment students were encountered a lush array of colors and textures beside visual and kinesthetic components. As a result, their imagination were awakened and provided them with different options of discovering and creating story. In the current study the researchers examined the effect of a new process, in which learners are thoroughly exposed to the poems, visualizing the represented images. They learn how to select the words to bring the images on a paper. In fact the creativity of the poet in arranging the words into freely expressing thoughts and ideas inspires and teaches students to promote creativity in their writing. In this process, imagination and poetry writing are not two separate independent variables. Instead, they are two integrated steps that form one independent variable, whose effect will be examined on writing creativity as a dependent variable.

\section{PROCEDURE OF THE STUDY}

The current study is a quasi-experimental research. Subjects of this study were fifty intermediate level EFL learners (including male and female) aged between 13 to 16 years old. To assess the writing creativity of students, TOEIC writing test was given to see how their writings were creative. The test is suitable and more practical due to the writing level of our subjects and it is a valid test too. The Writing test includes three different task types. The first task type (Questions 1-5) is rated on a scale of 0 to 3, the second task type (Questions 6-7) is rated on a scale of 0 to 4, and the last task type (Question 8) is rated on a scale of 0 to 5 . The sum of all ratings is converted to a scaled score of 0 to 20.Among eight intermediate level classes who were willing to participate, two classes were randomly selected. The classes were randomly assigned into control and experimental groups. TOEIC writing test was assigned as pretest, which contained parallel forms of writing and were scored by two independent raters. The homogeneity of groups was determined by comparing their mean scores. The researchers provided a test of writing and its parallel form as pretest and administered to the students. The subjects answered parallel forms and the researchers asked two independent raters to score them. The Person Product Moment Correlation Coefficient was applied and the reliability of the scores in terms of scoring and parallel form was calculated.

In the next step the mean scores of subjects (pre-test) in both groups were compared to ensure that subjects were divided in groups in a homogenized way. Subjects in control group continued the predetermined syllabus of the institutes by the same teacher. The subjects in experimental groups went through ten sessions treatment and each session a poem was read by the teacher and students read it many times and some explanations were presented by the teacher. Then, subjects were asked to visualize and write a poem. They analyzed and interpreted the poems afterwards.

The teacher assigned posttest and records the scores. The paired sample t-test was applied on the scores. The mean scores of both groups in pretest and posttest were compared and the differences were checked to see whether the independent variable has affected the dependent variable. To calculate the reliability of the test a parallel form of that test was designed and all 50 subjects were asked to answer both parallel forms. The parallel tests were scored and the scores were correlated to see if their correlation is significant or not. To do this the researchers used Pearson Product Moment Coefficient Correlation.

\section{TREATMENT AND WRITING CREATIVITY}

This study treated subjects in the experimental group for 10 sessions. Each session the teacher reads a poem. She describes the scene and the events in the poems and elaborates on the possible meanings inferred 
from the lines. She explains the literary devices, used in the poem, such as simile, metaphor, allegory and hyperbole. She challenges students' thinking and imagination to form and increase their interest and attention towards the images, ideas and setting of the poems. The students were asked to visualize the topic and the events represented by the teacher while reading the lines and focusing on the images. The teacher asks them to create their own images and try tore write the poem. Rhyming is not important and they should use their imagination and write a creative poem or even a creative piece of writing. After ten sessions, the same writing test in the pretest was administered as posttest. One sample t-test was applied and the mean scores of subjects in experimental group were calculated by the use of SPSS. Obviously, the mean score of experimental group is about 14.76. The results of pretest and posttest of subjects in experimental group are summarized below.

Table1. Pretest and posttest of experimental group

\begin{tabular}{|ll|c|c|c|c|}
\hline & Mean & & $\begin{array}{c}\text { Std. } \\
\text { Deviation }\end{array}$ & Std. Error Mean \\
\hline \multirow{2}{*}{ Pair 1 } & Pre-test & 11.0417 & 25 & 3.19825 & .58392 \\
& Posttest & 14.7583 & 25 & 3.16737 & .57828 \\
\hline
\end{tabular}

By comparing the results of experimental group in pretest and posttest we can conclude that there has been a significant change in the score of subjects from pretest and posttest. The mean scores of experimental subjects in pretest have been 11.04 while after the treatment, it has improved to 14.76. The following table shows the result of applying paired sample $t$ test. This table helps us to conclude whether the results are significant or not.

\begin{tabular}{|c|c|c|c|c|c|c|c|c|c|}
\hline \multicolumn{10}{|c|}{ Table 2. the result of paired sample t test of experimental group in pretest and posttest } \\
\hline & & \multicolumn{5}{|c|}{ Paired Differences } & \multirow{3}{*}{$\mathrm{t}$} & \multirow{3}{*}{ df } & \multirow{3}{*}{$\begin{array}{l}\text { Sig.(2- } \\
\text { tailed) }\end{array}$} \\
\hline & & \multirow[t]{2}{*}{$\begin{array}{c}\text { Mea } \\
\mathrm{n}\end{array}$} & \multirow{2}{*}{$\begin{array}{l}\text { Std. } \\
\text { Deviat } \\
\text { ion }\end{array}$} & \multirow{2}{*}{$\begin{array}{l}\text { Std. } \\
\text { Error } \\
\text { Mean }\end{array}$} & \multicolumn{2}{|c|}{$\begin{array}{l}\text { 95\% Confidence } \\
\text { Interval of the } \\
\text { Difference }\end{array}$} & & & \\
\hline & & & & & Lower & Upper & & & \\
\hline pair 1 & $\begin{array}{c}\text { Pre-Post } \\
\text { test }\end{array}$ & $\begin{array}{l}- \\
3.71 \\
667\end{array}$ & $\begin{array}{c}2.389 \\
57\end{array}$ & .43627 & $\begin{array}{c}- \\
4.6089 \\
5\end{array}$ & $\begin{array}{c}- \\
2.8243 \\
9\end{array}$ & $\begin{array}{c}- \\
8.51 \\
9\end{array}$ & 29 & .000 \\
\hline
\end{tabular}

It shows that $\mathrm{t}=-8.519$ and $\mathrm{p}=0.000$. Since $\mathrm{t}=-8.519$ and $\mathrm{p}<0.001$, then the results are highly significant in 0.001 level of significance. Based on the compared pieces of writing and results of the analyzed data the researcher could conclude that poem writing and visualization had a significant effect on writing creativity of the students. Furthermore, the null hypothesis is rejected and the researcher can hypothesize that there is a significant effect between visualization and poem writing on students writing creativity. But it is not enough for concluding the usefulness of treatment on experimental group. To accomplish the conclusion, the researchers needed to check that whether it has been the result of treatment that caused changes in experimental group or this change has happened to control group too. As a result the researchers used one sample t-test and calculated the mean scores of control group in posttest and the result are shown in the following table.

\begin{tabular}{|c|c|c|c|c|c|}
\hline \multicolumn{6}{|c|}{ Table 3. the result of comparing pretest and posttest of control group } \\
\hline & & Mean & N & Std. Deviation & $\begin{array}{c}\text { Std. Error } \\
\text { Mean }\end{array}$ \\
\hline \multirow{2}{*}{ Pair 1 } & Pre-test control & 11.9167 & 25 & 3.68380 & .67257 \\
\cline { 2 - 6 } & Posttest control & 11.9750 & 25 & 3.35304 & .61218 \\
\hline
\end{tabular}

As it can be observed, the mean score of posttest of control group is 11.97. To see if there is a difference between their mean scores in pretest and posttest paired sample t-test was applied and the result are shown in the above table. It shows that the mean score of control group has changed from 11.92 to 11.97. This change is very low and not significant enough. Thus, the researchers conclude that the changes in experimental 
group are more significant with 3.72 in mean scores in comparison to 0.05 changes in the mean score of control group. To see the significance of the changes from pretest to posttest session in control group, the result of paired sample $t$ test in the scores of control group in pretest and posttest are represented as below.

\begin{tabular}{|c|c|c|c|c|c|c|c|c|c|}
\hline & \multicolumn{8}{|c|}{$\begin{array}{l}\text { Table4. The results of paired sample } t \text { test of control group in pretest } \\
\text { and posttest }\end{array}$} \\
\hline & & \multicolumn{5}{|c|}{ Paired Differences } & & \multirow{3}{*}{ df } & \multirow{3}{*}{$\begin{array}{l}\text { Sig. (2- } \\
\text { tailed) }\end{array}$} \\
\hline & & \multirow[t]{2}{*}{ Mean } & \multirow{2}{*}{$\begin{array}{l}\text { Std. } \\
\text { Deviati } \\
\text { on }\end{array}$} & \multirow{2}{*}{$\begin{array}{l}\text { Std. } \\
\text { Error } \\
\text { Mean }\end{array}$} & \multicolumn{2}{|c|}{$\begin{array}{l}\text { 95\% Confidence } \\
\text { Interval of the } \\
\text { Difference }\end{array}$} & & & \\
\hline & & & & & Lower & Upper & & & \\
\hline $\begin{array}{c}\text { Pair } \\
1\end{array}$ & $\begin{array}{l}\text { Pre- } \\
\text { post } \\
\text { tests }\end{array}$ & -.05833 & 2.62258 & .47882 & $\begin{array}{c}- \\
1.03762\end{array}$ & 92096 & .12 & 29 & .904 \\
\hline
\end{tabular}

It illustrates that $t=-0.122$ and $p=0.904$. This means that since $p>0.5$ the changes in pretest and posttest are not significant. The importance of poetry as a tool for fostering writing creativity is illustrated in the above tables. Changes and improvements were observable in students' pieces of writing. Their writing improved in their last session assignments which were examined in posttest.

\section{CONCLUSION}

The current study sought to answer this question: Does the use of visualization and poetry writing promote writing creativity of the learners? For the answer, the researchers gathered the required data and examined the effect of visualization and poetry writing on writing creativity of learners. After the collection of the data, the data were analyzed and the mean score of control group in pretest was 11.92. This amount changed to 11.97 in the post test that means the mean score of subjects in control group has changed about 0.05 from pretest to post test. But the mean score of experimental group in pretest was 11.04 and it changed to 14.75 in posttest. The amount of the change in the means core of experimental group is 3.72, which is much more than the change in control group. The researcher compared the differences between students' writing creativity scores before and after the experimentation. The comparison of mean scores of two groups in pretest and posttest sessions reveals the positive effect of the treatment. EFL teachers can imply the findings of the study. They can teach poems in their classes and instruct students in how to communicate their message through visual imagery. Additionally, material developers can imply the findings of the study while they are developing materials for EFL learners. They can put some tasks in the books to ask EFL learners to write poems by visualizing some provided images. Furthermore, they can bring some poems as creatively written samples of language in the materials.

\section{REFERENCES}

[1] T. S. Kane, The Oxford essential guide to writing(New York: Oxford University Press)

[2] B.Barbot,,M. Tan, J.Randi,G. Santa-Donato and E. L. Grigorenko, Essential skills for creative writing: Integrating multiple domain-specific perspectives. Thinking Skills and Creativity, 7, 209-223.

[3] A.Yavuz, Enhancing creativity in the communicative language classroom through poetry as a literary genre, DilDergisi., 149. 64-79.

[4] C. Smith, Creative writing as an important tool in second language acquisition and practice. The Journal of Literature in Language Teaching, 2, 12-18.

[5] P. A. Llach, Teaching language through literature: The Waste Land in the ESL classroom. Odisea, 8, 7-17.

[6] Y. Kirkgoz, Using poetry as a model for creating English poems, Journal of Language and Linguistic Studies, 4(2), 94-106.

[7] L.Ward, Integrating poetry and writing: Ways in which to engage literacy learners. Practically Primary, 18(2), 17-20.

[8] B. Jeffrey, Creative teaching and learning: Towards a common discourse and practice. Cambridge Journal of Education, 36(3), 399-414.

[9] W. J. Glenn, Real writers as aware readers: Writing creatively as a means to develop reading skills. Journal of Adolescent and Adult Literacy, 51(1), 10-20.

[10] S. Chen, \& J. Zhou, Creative writing strategies of young children: Evidence from a study of Chinese emergent writing. Thinking Skills and Creativity, 5(3), 138-149.

[11] B.Olshansky, Making writing a work of art: Image-making within the writing process, .Language Arts, 71(5), 350356. 